\title{
Channel selection in e-commerce age: A strategic analysis of co-op advertising models
}

\author{
Yongmei Liu, Yuhua Sun, Junhua Hu \\ Business School of Central South University (China) \\ linyongmeicn@yaboo.com.cn,sybyxt@,126.com,bujunbua@,csu.edu.cn
}

Received November 2012

Accepted January 2013

\section{Abstract:}

Purpose: The purpose of this paper is to develop and compare two co-op advertising models: advertising model under traditional channel and co-op advertising model under dual channel, to select optimal channel structure to sell products for manufacturer and to derive optimal co-op advertising strategies for the manufacturer and the retailer.

Design/methodology/approach: Stackelberg game theoretical is used to develop two co-op advertising models: co-op advertising model under traditional channel and co-op advertising model under dual channel. Then we compare the two models to select optimal channel structure to sell products for manufacturer and to derive optimal co-op advertising strategies for the manufacturer and the retailer. Furthermore, we analyze the impact of product web-fit on these optimal strategies and illustrate by some numeral examples. Based on our results, we provide some significant theories and managerial insights, and derive some probable paths of future research.

Findings: We provide a framework for researching optimal co-op advertising strategies in a two-level supply chain considering different marketing channel structures. First, we discuss the traditional channel co-op adverting model and the dual channel co-op advertising model based on Stackelberg game theoretical, and we derive optimal co-op advertising strategies. Next, comparisons of these two channel structures are discussed and we find that the manufacturer always benefits from dual channel. But the retailer not always benefits from dual channel 
structure, and dual channel structure is better than retail channel with certain conditions. Also, the optimal co-op advertising strategies for the manufacturer and the retailer are obtained.

Research limitations/implications: First, we focus on the aforementioned two channel structures; a further comparison with other channel structures can be investigated. Second, we ignore some factors that influence the demand of product, such as service and price. We can do some researches from the point of these factors. Third, how demand uncertainty affects the channel selection and co-op advertising strategy is another interesting research item.

Practical implications: The manufacturer and the retailer know that the impact of co-op adverting on the demands of traditional channel and direct channel, both would like to choose reasonable strategies to improve the channel coordination. Therefore, it would be best if business managers conduct market survey before they start their co-op advertising campaign.

Originality/value: Two new co-op advertising models in E-commerce age are developed, and the impact of product web-fit on these optimal strategies are analyzed and illustrate by some numeral examples. In addition, optimal channel structure in E-commerce age are selected for manufacturer and the retailer.

Keywords: traditional channel, dual channel, channel selection, co-op advertising strategy, Stackelberg game

\section{Introduction}

The surge in the Internet and third part logistics over the past decades has significantly changed supply chain management and given business an unprecedented marketing opportunity. Firm can effectively handle order using the Internet and conveniently send products to customers using third part logistics. More and more manufacturers start to adopt direct channel to sell products and the introduction of direct channel has profound and lasting influence on channel selection of products (Dumrongsiri, Fan \& Jain, 2008). Comparing with any single channel, dual channel can better realize the market penetration. However, the existing of direct channel makes manufacturers to be the competitor of retailers and lead to channel conflict (Tsay \& Agrawal, 2004). Whether introducing direct channel into traditional channel or not is worth discussing. On the other hand, because co-op advertising increases the channel demand, it can partly alleviate channel conflict. Therefore, channel selection of products and co-op advertising strategies in e-commerce age are very important and interesting. 
Marketing channel is each link of the processing that products transfer from manufacturers to end customers or users. It not only makes firms meet customers' needs, but also makes firms to gain competitive edge (Kotler, 2000). However, previous analysis indicates that channel conflict emerges because manufacturers add direct channel to sell products. The literatures on multi-channel supply chain involving a direct channel and a traditional retail have been devoted to determining whether the manufacturer should add direct channel to its existing traditional channel. Rhee and Park (2000) develop a model in which a manufacturer has an online direct store, has an independent traditional retailer, or has both channel, and they reveal that dual channel is better than the other two channel structure when customers' valuations of the retail service are similar across segments. Chiang, Chhajed and Hess (2003) show that it is favorable for the manufacturer to set up a direct channel to compete with the retailer, they also recommend a Pareto zone where both the manufacturer and the retailer can be beneficial after the manufacturer add the direct channel. Chiang and Monahan (2005) compare traditional channel structure, direct channel structure and dual channel structure, and they propose that dual channel structure strategy outperforms the other two single channel structure strategies in most cases. Arya, Mittendorf and Sappington (2007) have the same conclusion marks. Tsay and Agrawal (2004) also address traditional channel and direct channel to show that both the manufacturer and retailer can benefit from dual channel strategy if the manufacturer is willing to reduce the wholesale price. To sum up, direct channel breaks the balance between the manufacturer and his downstream retailers, and reasonable channel choice can alleviate channel conflict. However, in aforementioned studies, little discussion has been given to co-op advertising, even though co-op advertising can partly alleviate channel conflict.

Co-op advertising is an interactive relationship between the manufacturer and the retailer in a supply chain ( $\mathrm{Li}$, Huang, Zhu \& Chau, 2002). In general, the manufacturer adopts co-op advertising to motivate the retailer sales and influence potential consumers' purchasing behavior to increase total demand. Many industries adopt co-op advertising which play a significant promotional role for many manufacturers and retailers (Huang \& Li, 2001; Huang, Li \& Mahajan, 2002; Li et al., 2002). Compared with 1987, co-op advertising expenditure of U.S. companies is increasing by about 40 billion. This increase indicates that the importance to research co-op advertising. In the marketing and management literatures, co-op advertising models in supply chain including manufacturer and retailers have focused on game theoretical to explore the role of co-op advertising in channel coordination. For example, Dant and Berger (1996), Bergen and John (1997), Kim and Staelin (1999), Huang et al. (2001), Huang et al. (2002), Li et al. (2002), and Karry and Zaccour (2006). However, these literatures focus on co-op advertising strategy in single channel structure, little on co-op advertising in multichannel even though more and more manufacturers add direct channel to its existing traditional channel. Yan, Ghose and Bhatnagar (2006) discuss Stackelberg game and Bertrand 
game for a price and operative advertising model in dual channel supply chain. This paper does not make co-op advertising expenditure as decision variable and co-op advertising does not increase the demand of products, only changes distributed proportion of the demand between traditional channel and direct channel. In fact, co-op advertising can offer customers the information of products and thus co-op advertising increases the demand of products.

In general, there has been a scarcity of models that deal with channel selection and co-op advertising strategies in multi-channel supply chain. This paper considers a supply chain including one manufacturer and one retailer, but it differs from previous works in several ways. First, this study considers the co-op advertising expenditure undertaken by the manufacturer and the retailer, and co-op advertising can increase the demand of direct channel and traditional channel. Specially, the impact of co-op advertising on the demand of direct channel is different from the impact of co-op advertising on the demand of traditional channel. In a two-level supply chain setting, the retailer's advertising campaign encourages potential customers to purchase the products, and the manufacturer can gain from the advertising campaign. The manufacturer undertakes the partly expenditure of retailer's advertising, namely co-op advertising. In addition, because the characteristics the two channels are different, the impacts of co-op advertising on the two channels are different too. Second, this study makes retailer's co-op advertising expenditure and manufacturer's fraction of co-op advertising expenditure as decision variables, and we derive optimal market strategies in ecommerce age. In our study, we use Stackelberg game theoretical to develop two co-op advertising models: co-op advertising model under traditional channel and co-op advertising model under dual channel. We address channel selection and co-op advertising strategies for the manufacturer, and co-op advertising strategy for the retailer. Furthermore, we also focus on the impact of product web-fit on these optimal strategies and identify probable paths of future research.

The remainder of this study is organized as follows: Section 2 outlines the model framework and the necessary assumptions and notations. Section 3 proposes traditional channel co-op advertising model and dual channel co-op advertising model, and then analyze the two models. Finally, the two co-op advertising models are compared and optimal marketing strategies. A numerical study is provided in Section 4. Conclusions are drawn in Section 5.

\section{Model framework}

We consider a two-level supply chain including one manufacturer and one retailer. We study and compare two different supply chain scenarios as illustrated in Fig. 1. Scenario R represents a traditional channel supply chain structure in which the manufacturer sells products through the retailer. Scenario RD is dual channel: direct channel, namely the manufacturer sells 
products to end customers directly; traditional channel, namely the manufacturer sells products to the retailer and the retailer sells product to end customers.

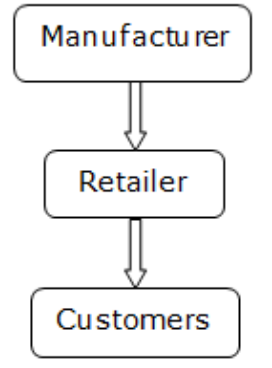

Scenarios R

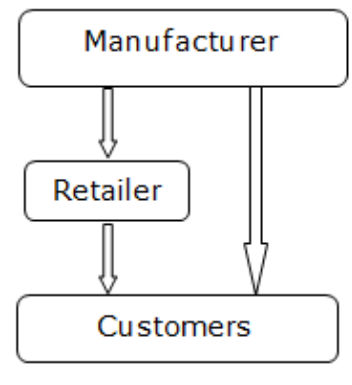

Scenarios R D

Figure 1 . The supply chain structure of Scenarios R, RD

We assume that there is only one kind of product for sale. We use $D_{\mathrm{d}}$ to represent the demand of direct channel and $D_{r}$ to represent the demand of traditional channel. The demand of each channel is assumed to be affected mainly by co-op advertising. As in Huang, Yang and Zhang (2011), we assume that the demands of direct channel and traditional channel are influenced by co-op advertising in different ways. Thus in Scenario $R$, we have

$$
\begin{aligned}
& D_{r-R}=a+k_{r} \sqrt{A_{R}} \\
& D_{d-R}=0
\end{aligned}
$$

In Scenario RD, we have

$$
\begin{aligned}
& D_{r-R D}=(1-\theta) a+k_{r} \sqrt{A_{R D}} \\
& D_{d-R D}=\theta a+k_{d} \sqrt{A_{R D}}
\end{aligned}
$$

where a represents base demand; $k_{r}$ and $k_{d}$ represent the impact factors of co-op advertising on the demand of retail channel and direct channel, respectively, and the impact of co-op advertising on the demand of direct channel is different from the impact of co-op advertising on the demand of traditional channel; $\theta$ represents the product web-fit, which is the compatibility of the product with web direct channel according to the characteristics of the product and the nature of web direct channel, $0 \leq \theta \leq 1$, where 0 represents that the products have no compatibility with web direct channel and 1 represents that the products complete compatibility with web direct channel; A represents the retailer's co-op advertising expenditure.

The manufacturer's marginal profit for each unit to be sold in traditional channel is $\rho_{\mathrm{m} 1}$, and the manufacturer's marginal profit for each unit to be sold in direct channel is $\rho_{\mathrm{m} 2}, 0<\rho_{\mathrm{m} 1}<\rho_{\mathrm{m} 2}$, 
namely the price of direct channel is larger than the wholesale price; the retailer's marginal profit for each unit to be sold is $\rho_{\mathrm{r}}$.

The fraction of co-op advertising expenditure which the manufacturer will to share with the retailer is $t$, which is the manufacturer's co-op advertising strategy.

In Scenario R, the manufacturer's, the retailer's and the supply chain's profit functions are as the following:

$$
\begin{aligned}
& \pi_{m-R}=\rho_{m 1} D_{r-R}+\rho_{m 2} D_{d-R}-t_{R} A_{R} \\
& \pi_{r-R}=\rho_{r} D_{r-R}-\left(1-t_{R}\right) A_{R} \\
& \pi_{t-R}=\pi_{m-R}+\pi_{r-R}=\rho_{m 1} D_{r-R}+\rho_{m 2} D_{d-R}+\rho_{r} D_{r-R}-A_{R}
\end{aligned}
$$

In Scenario RD, the manufacturer's, retailer's and supply chain's profit functions are as the following:

$$
\begin{aligned}
& \pi_{m-R D}=\rho_{m 1} D_{r-R D}+\rho_{m 2} D_{d-R D}-t_{R D} A_{R D} \\
& \pi_{r-R D}=\rho_{r} D_{r-R D}-\left(1-t_{R D}\right) A_{R D} \\
& \pi_{t-R D}=\pi_{m-R D}+\pi_{r-R D}=\rho_{m 1} D_{r-R D}+\rho_{m 2} D_{d-R D}+\rho_{r} D_{r-R D}-A_{R D}
\end{aligned}
$$

We use a Stackelberg leader-follower game to describe the relationship between the manufacturer and the retailer. The manufacturer as the leader decides the fraction of co-op advertising expenditure, and then the retailer as the follower decides co-op advertising expenditure. This paper first analysis traditional channel situation (Scenario R), and dual channel situation (Scenario RD). Then compare the two scenarios to select optimal channel to sell products for the manufacturer and make optimal co-op advertising strategies for the manufacturer and the retailer.

\section{The model}

In this paper, co-op advertising models for the two-level supply chain are derived from traditional channel (Scenario R) and dual channel (Scenario RD). In Scenario R, each member in the supply chain focuses on maximizing their own profit, without channel conflict. On the other hand, in Scenario RD, the upstream manufacturer and downstream retailer have co-op relationship, but they compete with each other, too. The issue that which channel structure is better for the manufacturer and the retailer is worth researching. We will first demonstrate the models of traditional channel and dual channel. Then we compare the two scenarios to select optimal market strategies. 


\subsection{Traditional channel supply chain decision}

When the manufacturer only sets up traditional channel, the retailer does not compete with the direct channel owned by the manufacturer and there is no channel conflict. The manufacturer and the retailer make decisions to maximize their profits. In this paper, our Stackelberg model leader is the manufacturer, who acts as the first mover by choosing the fraction of co-op advertising expenditure. The retailer, acting as the follower, then chooses optimal co-op advertising strategy based on the manufacturer's decision.

First, we analyze the retailer's optimal co-op advertising strategy, in the second stage of the game. The retailer's profit maximization problem can be expressed as:

$$
\max \pi_{r-R}\left(A_{R}\right)=\rho_{r}\left(a+k_{r} \sqrt{A_{R}}\right)-\left(1-t_{R}\right) A_{R}
$$

It is easy to prove that $\pi_{r-R}\left(A_{R}\right)$ is a concave function of $A_{R}$, the optimal value of the co-op advertising expenditure is determined by setting the first derivative of $\pi_{r-R}\left(A_{R}\right)$ with $A_{R}$ to be zero as follows:

$$
A_{R}^{*}=\left[\frac{\rho_{r} k_{r}}{2\left(1-t_{R}\right)}\right]^{2}
$$

The optimal profit of the retailer as follows:

$$
\pi_{r-R}{ }^{*}=\rho_{r} a+\frac{\rho_{r}{ }^{2} k_{r}{ }^{2}}{4\left(1-t_{R}\right)}
$$

Property 1: Under the traditional channel supply chain setting,

(a) the retailer's optimal co-op advertising expenditure $A_{R}^{*}$ increases with the impact of co-op advertising on the demand of traditional channel $k_{R}$, the fraction of co-op advertising expenditure which manufacturer will to share with retailer $t_{R} ;$

(b) the retailer's optimal profit $\pi_{r-R}{ }^{*}$ increases with the impact of co-op advertising on the demand of traditional channel $k_{r}$, the fraction of co-op advertising expenditure which manufacturer will to share with retailer $t_{R}$.

Property 1(a) indicates that when co-op advertising more efficiently promotes the products in traditional channel and the manufacturer undertakes more fraction of the retailer's co-op advertising expenditure, and the retailer would like to invest more into co-op advertising campaign. It is intuitive that the retailer's co-op advertising efficiency of traditional channel increase, the demand of traditional channel is high, and the retailer's profit is high. The retailer would like to invest more into co-op advertising campaign. On the other hand, the more the 
manufacturer would like to share, the less the retailer's co-op advertising expenditure. Namely, the retailer can benefit more from co-op advertising campaign and would like to invest more. These results in Property 1 (b) reveal that when co-op advertising more efficiently promotes the product in traditional channel and the manufacturer undertakes more of the retailer's co-op advertising expenditure, the retailer's profit will to be more. It is also reasonable to expect that when the retailer's co-op advertising efficiency of the traditional channel and the manufacturer's co-op advertising apportionment fraction are more, the demand of traditional channel is higher and the retailer's co-op advertising expenditure is less. Therefore, the retailer's profit will to be more.

Second, we analyze the manufacturer's optimal co-op advertising strategy, in the first stage of the game. The manufacturer will choose optimal fraction of co-op advertising expenditure according to the retailer's optimal co-op advertising strategy.

Substituting (1) into (2) and (12) into (5), we derive the manufacturer's profit function:

$$
\pi_{m-R}\left(t_{R}\right)=\rho_{m 1}\left(a+k_{r} \sqrt{A_{R}}\right)-t_{R} A_{R}
$$

It is easy to prove that $\pi_{m-R}\left(t_{R}\right)$ is a concave function of $t_{R}$, the optimal value of the fraction of co-op advertising expenditure is determined by setting the first derivative of $\pi_{m-R}\left(t_{R}\right)$ with $t_{R}$, to be zero as follows:

$$
t_{R}^{*}=\frac{2 \rho_{m 1}-\rho_{r}}{2 \rho_{m 1}+\rho_{r}}
$$

The optimal profits of the retailer and the manufacturer as follows:

$$
\begin{aligned}
& \pi_{r-R}{ }^{*}=\rho_{r} a+\frac{1}{8} k_{r}^{2} \rho_{r}\left(2 \rho_{m 1}+\rho_{r}\right) \\
& \pi_{m-R}^{*}=\rho_{r} a+\frac{1}{16} k_{r}^{2}\left(2 \rho_{m 1}+\rho_{r}\right)^{2}
\end{aligned}
$$

Property 2: Under the traditional channel supply chain setting,

(a) the manufacturer's optimal fraction of co-op advertising expenditure $t_{R}{ }^{*}$ increases with the manufacturer's marginal profit for each unit to be sold in retail channel $\rho_{\mathrm{m} 1}$, but decreases with the retailer's marginal profit for each unit to be sold $\rho_{r}$;

(b) the manufacturer's optimal profit $\pi_{m-R}{ }^{*}$ increases with the impact of co-op advertising on the demand of retail channel $k_{r}$. 
Property 2(a) means that when the manufacturer's marginal profit for each unit to be sole in retail channel is high and the retailer's marginal profit for each unit to be sold is less, the manufacturer would like to share more of the retailer's co-op advertising expenditure. It is intuitive that if the manufacturer's marginal profit for each unit to be sold in retail channel is more, he would like to share more of co-op adverting. However, if the retailer's marginal profit for each unit to be sold in retail channel is less, he would like to share more of co-op adverting to encourage the retailer. Property 2(b) shows that when the impact of co-op advertising on the demand of traditional channel, the manufacturer's profit will to be more. It is also intuitive that when the retailer's co-op advertising efficiency of the traditional channel are more, the demand of traditional channel is higher. Therefore, the manufacturer's profit will to be more.

\subsection{Dual channel supply chain decision}

When the manufacturer adds direct channel to its existing traditional channel, the retailer competes with the direct channel owned by the manufacturer. The relationship between the manufacturer and the retailer is not only co-op, but also competitive. And the change of the manufacturer's role results in channel conflict. On the other hand, co-op advertising not only increases the demand of traditional channel, but also increases the demand of direct channel in dual channel supply chain. In addition, the influence of co-op advertising on direct channel demand is different from the impact of co-op advertising on the demand of traditional channel. Therefore, how the manufacturer and the retailer make their decisions is worth researching in this channel structure. The Stackelberg game is used in dual channel supply chain, too. Thus, the retailer's profit maximization problem in Scenario RD can be expressed as follows:

$$
\max \pi_{r-R D}\left(A_{R D}\right)=\rho_{r}\left[(1-\theta) a+k_{r} \sqrt{A_{R D}}\right]-\left(1-t_{R D}\right) A_{R D}
$$

Using a similar method developed in traditional channel, optimal solutions of the retailer's coop advertising can be obtained by solving the first order equation of (19), as follows:

$$
A_{R D}^{*}=\left[\frac{\rho_{r} k_{r}}{2\left(1-t_{R D}\right)}\right]^{2}
$$

The optimal profit of the retailer as follows:

$$
\pi_{r-R D}{ }^{*}=(1-\theta) \rho_{r} a+\frac{\rho_{r}{ }^{2} k_{r}{ }^{2}}{4\left(1-t_{R D}\right)}
$$

We have seen in Property 1 that under traditional channel setting, the retailer's co-op advertising expenditure always increases with the impact of co-op advertising on the demand of retail channel $k_{r}$, and the manufacturer's fraction of co-op advertising expenditure $t_{R D}$. We also see that the retailer's profit always increases with the impact of co-op adverting on the 
demand of traditional channel $k_{r}$, and the manufacturer's fraction of co-op advertising expenditure $t_{R D}$. It turns out that these results hold for dual channel as well. In addition, the retailer's profit decreases with the product web-fit $\theta$. It is reasonable to expect that when the product is more compatible with web direct channel, the demand of direct channel increases and the base demand of traditional channel decreases. Therefore, the retailer's profit decreases with the product web-fit $\theta$.

Then, we analyze the manufacturer's optimal co-op advertising strategy, in the first stage of the game. Substituting (3) into (4) and (19) into (8), we derive the manufacturer's profit function:

$$
\pi_{m-R D}\left(t_{R D}\right)=\rho_{m 1}\left[(1-\theta) a+k_{r} \sqrt{A_{R D}}\right)-t_{R D} A_{R D}
$$

Using a similar method developed in traditional channel, the optimal value of manufacturer's fraction of co-op advertising expenditure is determined by setting the first derivative of $\pi_{m-R D}\left(t_{R D}\right)$ with $t_{R D}$, to be zero as follows:

$$
t_{R D}^{*}=\frac{2 \rho_{m 1} k_{r}+2 \rho_{m 2} k_{d}-\rho_{r} k_{r}}{2 \rho_{m 1} k_{r}+2 \rho_{m 2} k_{d}+\rho_{r} k_{r}}
$$

The optimal profits of the retailer and the manufacturer as follows:

$$
\begin{aligned}
& \pi_{r-R D}{ }^{*}=\rho_{r}(1-\theta) a+\frac{1}{8} \rho_{r} k_{r}\left(2 \rho_{m 1} k_{r}+\rho_{m 2} k_{d}+\rho_{r} k_{r}\right) \\
& \pi_{m-R D}^{*}=\rho_{m 1}(1-\theta) a+\rho_{m 2} \theta a+\frac{1}{16}\left(2 \rho_{m 1} k_{r}+2 \rho_{m 2} k_{d}+\rho_{r} k_{r}\right)^{2}
\end{aligned}
$$

Property 3: Under the dual channel supply chain setting,

(a) the manufacturer's optimal fraction of co-op advertising expenditure $t_{R D}{ }^{*}$ increases with the manufacturer's marginal profit for each unit to be sold in retail channel $\rho_{\mathrm{m} 1}$, the manufacturer's marginal profit for each unit to be sold in direct channel $\rho_{\mathrm{m} 2}$, and the impact of co-op advertising on the demand of direct channel $k_{d}$; but decreases with the retailer's marginal profit for each unit to be sold $\rho_{\mathrm{r}}$ and the impact of co-op advertising on the demand of retail channel $k_{r}$;

(b) the manufacturer's optimal profit $\pi_{\mathrm{m}-\mathrm{RD}}{ }^{*}$ increases with the impact of co-op advertising on the demand of retail channel $k_{r}$, the impact of co-op advertising on the demand of dual channel $k_{d}$ and the product web-fit $\theta$. 
We have seen the results in Property 2 that under the traditional channel setting are same with Property 3. In addition, Property 3(a) means that when the manufacturer's marginal profit for each unit to be sole in direct channel is high, the manufacturer would like to share more of the retailer's co-op advertising expenditure. It is intuitive that if the manufacturer's marginal profit for each unit to be sold in direct channel is more, he would like to share more of co-op adverting. Property 3(a) also reveals that the manufacturer would like to share more of the retailer's co-op advertising expenditure if the impact of co-op advertising on the demand of direct channel is larger and the impact of co-op advertising on the demand of traditional channel is smaller. If the manufacturer knows the impact of co-op advertising on the demand of direct channel and the demand of retail channel, he would like to share reasonable with the retailer to improve the channel coordination. Property 3(b) also shows that when co-op advertising more efficiently promotes the product in direct channel, and the product is more compatible with web direct channel, the manufacturer's profit will to be more. It is also intuitive that when the retailer's co-op advertising efficiency of direct channel is more, the demand of direct channel is higher, and the manufacturer's profit will to be more.

\subsection{Model comparison}

In this section, we discuss whether the manufacturer and the retailer would be better off in RD than in $\mathrm{R}$ and derive the differences between the optimal strategies in the two scenarios and develop some managerial guidelines. Comparing the corresponding strategies in Scenarios $R$ and $\mathrm{RD}$, we obtain the following results.

\section{Theorem 1}

(a) For the manufacturer, Scenario RD outperforms Scenario $R, \pi_{m-R D}{ }^{*}>\pi_{m-R}{ }^{*}$; for the retailer, Scenario RD outperforms $R, \pi_{r-R D}{ }^{*}>\pi_{r-R}{ }^{*}$, if

$$
\theta<\frac{\rho_{m 2} k_{r} k_{d}}{4 a}
$$

(b) The manufacturer's fraction of co-op advertising expenditure in Scenario RD is higher than the retailer's co-op adverting expenditure in Scenario $R, t_{R D}{ }^{*}>t_{R}{ }^{*}$;

(c) The retailer's co-op advertising expenditure in Scenario RD is higher than the retailer's coop adverting expenditure in Scenario $\mathrm{R},{A_{R D}}^{*}>A_{R}{ }^{*}$.

Theorem 1(a) reveals that the manufacturer always benefits from adding a direct channel. It is intuitive because the existence of direct channel results in demand transfer from traditional channel to direct channel, and generates more profits for the manufacturer by owning the direct channel. Therefore, the manufacturer always chooses dual channel to sell product. Theorem 1(a) also shows that the retailer can perform better in Scenario RD than in Scenario 
$\mathrm{R}$ when the value of the product web-fit is smaller than some threshold. It is also reasonable that when the product is less compatible with web direct channel, the demand transfer from traditional channel to direct channel is small, the retailer can benefit more from Scenario RD than Scenario R. Theorem 1(b) indicates that the manufacturer share more with the retailer if he adds a direct channel. As showed in Theorem 1(a), the manufacturer's profit in Scenario RD is larger than in Scenario $\mathrm{R}$, but if and only if the product web-fit $\theta<\frac{\rho_{m 2} k_{r} k_{d}}{4 a}$, the retailer's profit in Scenario RD is larger in Scenario R. In order to remit channel conflict, the manufacturer will always share more fraction of co-op advertising expenditure with the retailer. Thus, the retailer increases co-op advertising expenditure to attract more potential customers to purchase the products, and then the co-op advertising campaign can increase the retailer's own profit, as showed in Theorem 1(c).

\section{Numerical examples}

The decision policies proposed in this study can be applied in solving the co-op advertising for the supply chain involving one retailer and one manufacturer. While our findings can be derived analytically, the analytical expressions are too complex to provide meaningful insights. Thus in this section, some numerical examples are given to illustrate the effect of changes in product web-fit on the manufacturer's profit, the retailer's profit and the profit of supply chain system. For our numerical examples, the basic settings with respect to the parameters are summarized in Table 1.

\begin{tabular}{|l|r|}
\cline { 2 - 2 } \multicolumn{1}{c|}{} & Base values \\
\hline The base demand of product(a) & 200 \\
\hline $\begin{array}{l}\text { The manufacturer's marginal profit for each unit to be sold } \\
\text { in retail channel }\left(\rho_{m 1}\right)\end{array}$ & 2 \\
\hline $\begin{array}{l}\text { The manufacturer's marginal profit for each unit to be sold } \\
\text { in direct channel }\left(\rho_{m 2}\right)\end{array}$ & 8 \\
\hline The retailer's marginal profit for each unit to be sold $\left(\rho_{r}\right)$ & 1.2 \\
\hline $\begin{array}{l}\text { The impact of co-op advertising on the demand of } \\
\text { traditional channel }\left(k_{r}\right)\end{array}$ & 1.8 \\
\hline $\begin{array}{l}\text { The impact of co-op advertising on the demand of direct } \\
\text { channel }\left(k_{d}\right)\end{array}$ & \\
\hline
\end{tabular}

Table 1. Parameters setting in our numerical examples

Figure 2 reveals that profit of the supply chain in Scenario RD is positively related to the product web-fit, but profit of the supply chain in Scenario $R$ is not related to the product webfit. Because traditional channel does not have web direct channel, the demand of traditional channel is not related to the product web-fit. Also, we observed that profit of the supply chain in Scenario RD is higher than profit of the supply chain in Scenario R settings. Therefore, for the supply chain, it is better to adopt dual channel. However, the manufacturer and the retailer are independent, and the problem which channel structure is better for them is shown in Figure 2. 
Figure 3 indicates that the effect of changes in product web-fit on the manufacturer's profit, the retailer's profit under different scenarios. Similarly, the manufacturer's profit and the retailer's profit in Scenario $R$ are not related to the product web-fit. We also find that the manufacturer's profit in Scenario RD increases with the product web-fit, and the retailer's profit in Scenario RD decreases with the product web-fit. This result confirms our analytical observations from Proposition 3(b). Note worthily, when the product web-fit is less than 0.25 , the retailer's profit in Scenario RD is larger than the manufacturer's profit; but when the product web-fit is larger than 0.25 , the retailer's profit in Scenario RD is less than the manufacturer's profit.

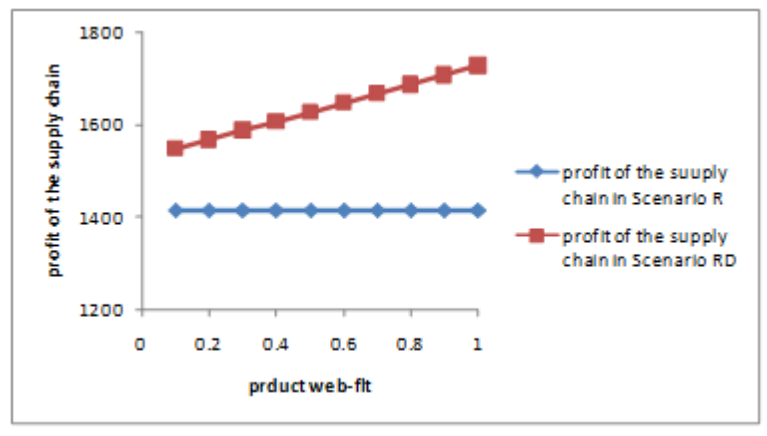

Figure 2. Profit of the supply chain under different scenarios

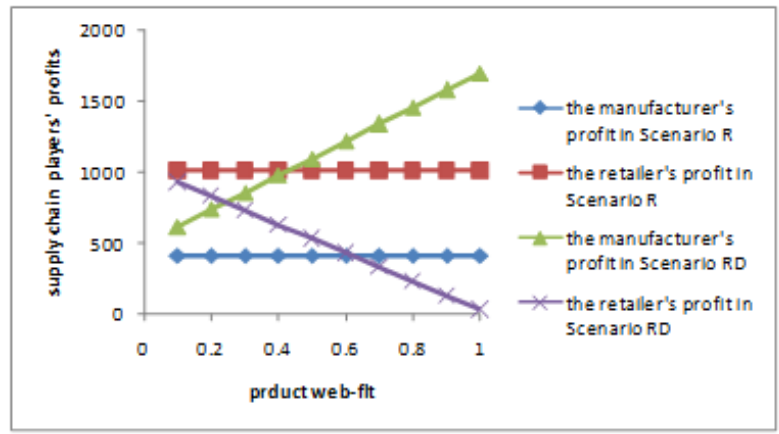

Figure 3. Supply chain players' profits under different scenarios

\section{Concluding remarks}

In this paper, we provide a framework for researching optimal co-op advertising strategies in a two-level supply chain considering different marketing channel structures. First, we discuss the traditional channel co-op adverting model and the dual channel co-op advertising model based on Stackelberg game theoretical, and we derive optimal co-op advertising strategies. Next, comparisons of these two channel structures are discussed and we find that the manufacturer always benefits from dual channel. But the retailer not always benefits from dual channel structure, and dual channel structure is better than retail channel with certain conditions. Also, the optimal co-op advertising strategies for the manufacturer and the retailer are obtained. According to these results, we explore some important theories and managerial insights. Furthermore, our numerical examples illustrate the impact of product web-fit on these optimal market strategies.

More specifically, our study presents some managerial implications for business managers. If the manufacturer and the retailer know that the impact of co-op adverting on the demands of traditional channel and direct channel, both would like to choose reasonable strategies to improve the channel coordination. Therefore, it would be best if business managers conduct market survey before they start their co-op advertising campaign. 
This paper has its limitations. First, we focus on the aforementioned two channel structures; a further comparison with other channel structures can be investigated. Second, we ignore some factors that influence the demand of product, such as service and price. We can do some researches from the point of these factors. Third, how demand uncertainty affects the channel selection and co-op advertising strategy is another interesting research item.

\section{Support}

Foundation item(s): Project supported by the National Natural Science Foundation, China (No.71271219, 71071164); the Two-oriented Society Research Center of Central South University 985 Project under Grant (No.ZNLX1102); Program for New Century Excellent Talents in University by Ministry of Education, China (No. NCET-11-0519).

\section{References}

Arya, A., Mittendorf, B., \& Sappington, D.E. (2007). The Bright Side of Supplier Encroachment. Marketing Science, 26(5), 651-659. http://dx.doi.org/10.1287/mksc.1070.0280

Bergen, M., \& John, G. (1997). Understanding cooperative advertising participation rates in conventional channels. Journal of Marketing Research, 35(3), 357-369. http://dx.doi.org/10.2307/3151898

Chiang, W.K., \& Monahan, G. (2005). Managing inventories in a two-echelon dual-channel supply chain. European Journal of Operational Research, 162(2), 325-341. http://dx.doi.org/10.1016/j.ejor.2003.08.062

Chiang, W.K., Chhajed, D., \& Hess, J.D. (2003). Direct marketing, indirect profits: a strategic analysis of dual-channel supply chain design. Management Science, 49(1), 1-20. http://dx.doi.org/10.1287/mnsc.49.1.1.12749

Dant, R.P., \& Berger, P.D. (1996). Modeling cooperative advertising decisions in franchising. The Journal of the Operation Research Society, 47(9), 1120-1136.

Dumrongsiri, A., Fan, M., \& Jain, A. (2008). A supply chain model with direct and retail channels. European Journal of Operational Research, 187(3), 691-718. http://dx.doi.org/10.1016/j.ejor.2006.05.044

Huang, S., Yang, C., \& Zhang, X. (2011). Pricing and cooperative advertising decision models in dual-channel supply chain. Computer Integrated Manufacturing Systems, 17(12), 26832692. 
Huang, Z., \& Li, S.X. (2001). Cooperative advertising models in a manufacturer-retailer supply chain: A game theory approach. European Journal of Operational Research, 135(3), 527-544. http://dx.doi.org/10.1016/S0377-2217(00)00327-1

Huang, Z.M., Li, S.X., \& Mahajan, V. (2002). An analysis of manufacturer-retailer supply chain coordination in cooperative advertising. Decision Sciences, 33(3), 1-20. http://dx.doi.org/10.1111/j.1540-5915.2002.tb01652.x

Karry, S., \& Zaccour, G. (2006). Could cooperative advertising be a manufacturer's counterstrategy to store brands. Journal of Business Research, 59(9), 1008-1015. http://dx.doi.org/10.1016/j.jbusres.2006.05.002

Kim, S.Y., \& Staelin, R. (1999). Manufacturer allowances and retailer pass-through rates in a competitive environment. Management Science, 18(1), 59-76.

Kotler, P. (2000). Marketing Management, (10th Ed.). Beijing, China: Tsinghua University Press.

Li, S.X., Huang, Z., Zhu, Z., \& Chau, P.Y.K. (2002). Cooperative advertising, game theory and manufacturer-retailer supply chains []].Omega, 30(5), 347-360. http://dx.doi.org/10.1016/S0305-0483(02)00051-8

Rhee, B., \& Park, S.Y. (2000). Online stores as a new direct channel and emerging hybrid channel system. Working paper.

Tsay, A.A., \& Agrawal, M. (2004). Channel conflict and coordination in the e-commerce age. Production and Operations Management, 13(1), 93-110. http://dx.doi.org/10.1111/j.19375956.2004.tb00147.x

Yan, R., Ghose, S., \& Bhatnagar, A. (2006). Cooperative advertising in a dual channel supply chain. International Journal of Electronic Marketing and Retailing, 1(2), 99-114. http://dx.doi.org/10.1504/IJEMR.2006.011028

Journal of Industrial Engineering and Management, 2013 (www.jiem.org)

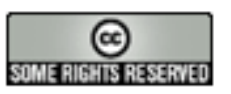

El artículo está con Reconocimiento-NoComercial 3.0 de Creative Commons. Puede copiarlo, distribuirlo y comunicarlo públicamente siempre que cite a su autor y a Intangible Capital. No lo utilice para fines comerciales. La licencia completa se puede consultar en http://creativecommons.org/licenses/by-nc/3.0/es/ 